\title{
URBANIZING SOUTHWARDS: PLANNING DEVELOPMENT POSSIBILITIES FOR MINDANAO, THE PHILIPPINES, AS A SOCIOPOLITICAL SIDE OF GEOTECHNICS IN SOUTHEAST ASIA
}

\author{
José Edgardo GOMEZ, Jr. ${ }^{1}$
}

DOI: 10.21163/GT_2019. 141.20

\begin{abstract}
:
Riding a wave of popular dissatisfaction with traditional politicians, a majority of the Philippine population elected as President the tough-talking Rodrigo Duterte of Davao City last 2016 - the first chief executive from the "frontier area" of Mindanao, a bountiful land of mixed Christian, Muslim, and indigenous tribal populations - and a major island which he promised to prioritize, refocusing development away from the northern capital of Manila. Taken together with integration of the Association of Southeast Asian Nations (ASEAN), at least on formal paper agreements, the development of the southern Philippines becomes a logical and practical priority. This research surveys and analyzes the emerging policies and key national-level planning documents that signal the shift of infrastructure and transport linkages to Mindanao, with an eye towards possible trade-related enhancements with northern Indonesia and Malaysia. It critically examines what government proposes (or is already building), and shows where decisions appear to be correct, as well as where they seem ambiguous, or even inappropriate and thus unlikely to succeed, especially in the way sociopolitical aspects complement geospatial techniques. It is argued how a turn southward is probably in the best interests both of social equity inside the state, and cross-country benefits for the Philippines and its ASEAN neighbors.
\end{abstract}

Key-words: ASEAN integration, Infrastructure, Mindanao, Philippines, Geographic links.

\section{INTRODUCTION}

Unprecedented in the political history of the Republic of the Philippines was the election last 2016 of the tough-talking Rodrigo Duterte as President. He was elected based substantially on the record of his iron rule as mayor of Davao City, a bastion of progress and peace among the usually strife-torn and impoverished towns of Mindanao, the island that makes up the archipelago's southern bulk. As a politician from the "frontier area", Duterte promised to shift domestic investments and infrastructure spending to this bountiful land of mixed Christian, Muslim, and indigenous tribal populations, as guided by geotechnical and planning expertise. Together with integration of the Association of Southeast Asian Nations (ASEAN), at least on formal paper agreements, the focus of growth in Mindanao promises prosperity that will link to Indonesia and Malaysia. This paper critically examines the policies and actions of the nation's leadership, especially from a planning perspective, to determine how the Philippines is handling a long-needed infusion of development and social-equity in its southern provinces, as well as a transformation of potential into actual growth because of strengthened linkages with neighbors. The emphasis of the study shall be on urban and regional development and policy, particularly physical growth enablers in specific sites, because regional politics and spatial planning systems have an increasingly important role in the delineation of metropolitan areas or regions

${ }^{1}$ University of the Philippines, School of Urban \& Regional Planning, 1101 Quezon City, Metro Manila, the Philippines, jagomez@up.edu.ph. 
(Tonev et al., 2017) It is important for scholarly readers to know and analyze which plans and massive infrastructure development are now being implemented in Mindanao, at least for the next five years, because these activities have several economic effects on Southeast Asia, especially on the traffic of commodities and people between Indonesia, Malaysia, and the Philippines. The difference is already visibly pronounced: from near-zero or slow investment to a boom in markets due to the accelerated construction or upgrade of highways, airports, and seaports where few existed in the last 30 years.

The research asks the two questions: First, is there any qualitative or substantial difference in the spatial plans, programs, policies, or actions being done in Mindanao as a result of government's reprioritization? Second, How can this actually or potentially connect, with mutual benefit to neighboring states in the south, most logically Indonesia and Malaysia? The author hypothesized that indeed, there are measurable initiatives being done to further develop Mindanao that deserve closer analysis, in order to assess quality of infrastructure and other investments, as well as to appreciate the emerging flows of people, commodities and information across national borders.

From a geographic perspective, it is important to plan for such changes as they occur within a definable physical area, because without clearly specifying the territorial scope of the proposed intervention it is not possible to define a plan (Gomis \& Turon, 2017). The result of this study generally matched expectations and political rhetoric, although it also has shown that there is still a long way to go in terms of building durable infrastructure to serve long-term economic growth. The study is significant in so far as it will enable policymakers to fine-tune current and upcoming plans and programs for the urban and regional development of Mindanao. It is also important for their counterparts in ASEAN countries, who may set up complementary arrangements for linkage, and furthermore will contribute to the relatively modest scientific literature on spatial aspects of growth in the southern Philippines.

\section{REVIEW OF RELATED LITERATURE}

\subsection{Historical Settlement Policy and the Claim to the Periphery}

After the emergence of the post-colonial $3^{\text {rd }}$ World, governments in Southeast Asia in the last century devised different ways to gradually extend control from central areas to the periphery of the young nation-states. In countries like Malaysia and Indonesia, stateorganized migrants, sometimes called transmigrants in the social science literature, have received preferential support from the state to relocate to distant islands or sparselypopulated parts of the territory, sometimes at the expense of native populations' prior access to land, material resources, and employment (Barter \& Cote, 2015).

Similarly, in the Philippines, Filipino elite were known to have maneuvered to establish agricultural colonies in Mindanao (and other frontier islands like Mindoro and Palawan) as early as the 1917, in attempts to inveigle themselves into American colonial plans that might have developed these areas separately from the existing body politic (Suzuki, 2013). The result after long years resembles what Allen (2003) describes as the mosaic of the peri-urban, where urban, rural, and natural systems interface in configuration of spatial and political power whose sum is greater than its component parts. This stretching out of development into the remoter regions of natural territory would make these areas ripe for the next logical step of opening cross-border linkages a century thereafter. 


\subsection{Common Weaknesses and Potential Areas for Intervention in Southeast Asia}

Presently however, the peripheral areas between the states are subject to varying degrees of state control and investment, hence differ in imminent development potential. This asymmetry is both the driver and result of economic inequality in an increasingly prosperous Asia; more particularly for instance, spatial inequality in transport access is conditioned on uneven growth and requires substantial corrective public investments that anticipate the benefits of well-connected urban networks (Liu, Liang \& Derudder, 2017). Still, other areas are not deemed ripe for usage, because of lingering concerns about safety, say for instance of tourists in the eastern coast of Malaysia, bordering Indonesia and the Philippines, where religious-ethnic violence has occasionally flared (Yang et al., 2015). In other cases, older administrative restrictions might need to be overcome, such as where Malaysia continues to adhere to cabotage policies that bar larger flows of coastal trade from its neighbors (Suffian et al., 2013), or where the Philippines is suppressing sporadic terrorism in the islands of Sulu, which sit across the maritime passage southwards.

\subsection{Growth Triangles and Regional Development in Asia}

From a government long-term perspective however, these once-peripheral locations have now increasingly been considered as part of inter-state aggrupations that conceptually hold the potential for trade and new urban development. Since their introduction in the 1990s, such "growth triangles" have been portrayed as a uniquely Asian solution to strategic and administrative problems of regional cooperation (Waldron, 1997). These growth triangles are cooperative, geospatial and technical ventures consisting of GISreferenced infrastructure along with partial or preferential trading arrangements that aim to convert different factor endowments into complementarities designed to produce mutual advantage, and have already underwritten economic success in the South China area (Landingin \& Wadley, 2005). In Southeast Asia, the main sub-regional cooperation arrangements are: the Indonesia-Malaysia-Singapore Growth Triangle (IMS-GT); the Greater Mekong Subregion (GMS); the Indonesia-Malaysia-Thailand Growth Triangle (IMT-GT); and the Brunei-Indonesia-Malaysia-Philippines East ASEAN Growth Area (BIMP-EAGA), which all target synergetic development through cross-border cooperation. BIMP-EAGA's particular land area is over $1.6 \times 10^{6} \mathrm{~km}^{2}$, with sea area at least double that figure, and it encompasses a population of around $58 \times 10^{6}$ (Dent \& Richter, 2011).

The whole idea, if implemented properly over time, is to encourage the development of what Boons (2008) calls a regional industrial economy, which is all about closing material and energy loops among firms, just as the cooperative and spatial arrangements will promote self-organization and socioeconomic development by virtue of proximity. The use of growth triangles is appropriate for engendering international and cross-border local links, where none existed before, and lends itself to geospatial conceptualization.

\subsection{Key Features of Asian Urbanization}

Within that same Southeast Asian region, or its sub-regions, one needs to take note of dynamics one step closer to the ground: how urbanization proceeds apace because of, or as a planned catalyst of cross-border growth. Goh \& Bunnell (2013) remind us, at least from the Anglophone perspective, that the scholarly discourse on Southeast Asian urbanization has tended to be metrocentric, leading to bifurcated space in which the role of the city as civic space is relegated to transnational capital, but also where counter-movements rooted 
in culture and local politics may contest spaces of power, and where resources at the periphery may be recruited by both sides, for different purposes. In such mega-urban regions, the "urban field" of economic, social, and technological influence extends way beyond formal boundaries, and more inclusive development can be achieved in at least five ways: (a) by closely integrating rural and urban areas within mega-urban regions; (b) by including all levels of local governments in the city region in planned development and governance schemes; (c) by including all sectors of society, especially the poor and underprivileged in city region development; (d) by integrating all urban infrastructure and services in area-wide networks; and (e) by conceiving of city-region development as a policy instrument for achieving economic, social and environmental sustainability (Laquian, 2007). Just as growth has resulted in many cases, inequality has also arisen in such Asian contexts over the last two decades. Effects however, are highly country specific, with Philippine urbanization being a major driver of inequality (Kanbur \& Zhuang, 2013).

\subsection{Geospatial and Technical Considerations: the Philippine South}

To end this section a few notes are added here to familiarize the reader with the Philippines as a geographic entity. The present development trajectory of this archipelago is influenced to some degree by its movement towards decentralization, starting with The Local Government Code of 1991, which was consistent with a global trend towards increased regional autonomy and a disenchantment with central rule, considering that Metro Manila and its two adjacent regions produced some 55\% of GDP and had already $20 \%$ of the population, while Mindanao continued to have high poverty and the largest number of armed encounters from 1986 to 2003 (Balisacan et al., 2008). Mindanao itself is divided into six regions: IX (Zamboanga Peninsula), X (Northern Mindanao), XI (Davao, or Eastern Mindanao), XII (SOCCSKARGEN-South Cotabato, Cotabato, Sultan Kudarat, Sarangani, and the City of General Santos), XIII (Caraga) and AR\& MM (Autonomous Region of Muslim Mindanao). Notably, the same source mentioned that Mindanao has not emerged as infrastructure-deficient, showing that it has not been neglected by investment from the center, but rather that some local government units (LGUs) have been unable and unwilling to raise their own revenues, or have been unable to maintain a peace and order situation.

\section{METHODOLOGY, SCOPE, AND LIMITATIONS}

This research, undertaken between January 2016 and December 2017, was primarily qualitative-descriptive in nature and consisted of formal and informal interviews with knowledgeable persons (for example, from the Office of the President, the Housing and Urban Development Coordinating Council, and the Public Private Partnership Center, to name a few key agencies), all of whom were mid-level bureaucrats of Assistant Secretary rank or higher, or were consultants and officers with Mindanao-focused groups. The researcher made at least two (2) trips to Mindanao within the period, to Cagayan de Oro and to Butuan, to observe general urban development conditions on the ground.

To confirm the research, a survey and analysis of readily available national policies was done, which also took note of recent plans for Mindanao as a macro-region as well as its constituent provinces. The material surveyed covered the last decade through the present, although reference has also been made to long-standing laws that are relevant to the discussion herein, especially with an emphasis on physical and spatial development. 


\section{RESULTS, ANALYSIS, AND DISCUSSION}

\subsection{National Plans and Overall Direactions for Mindanao Development}

At the highest levels of government, the National Economic and Development Authority (NEDA) is responsible for producing plans in close coordination with the Office of the President, as well as with the various regional councils that aggregate development aspirations at the local level. A comparison was made of the Philippine Development Plans [PDPs] from the last decade and the current one which shall guide growth till 2022, and this revealed a definite multiplication of aspirational statements regarding Mindanao. From an urban planning perspective, the lead roles of Davao City and Zamboanga City remain, which have historically been the most practical large-scale connecting points to Indonesian and Malaysian ports, with General Santos City and Cotabato City coming as possible seconds. Meanwhile, the unique geographic location of Cagayan de Oro City, which also connects to nearby Iligan port, is an assurance of its continuing growth as trade corridor between more northerly islands and the rest of Mindanao and nation-states to the south. A second major emphasis of the national plans that now has more detailed text is the peacebuilding process in Mindanao, primarily directed to settle enmities and to share equal socioeconomic opportunities between Muslims and Christians. Whereas previous pronouncements only vaguely declared affirmative action, plans for the next six years specifically state that an infrastructure-rebuilding program for peace will be enhanced and implemented. The third major emphasis that now has concrete declarations in national plans is the affirmation of Mindanao as the country's food basket, as it has taken over this role in the last half-century, which was once held by rapidly urbanizing Luzon. Bananas, cacao, and fisheries are cited, as well as a specific road-building program, with emphasis on farmto-market roads and irrigation, especially for the drier Central Mindanao area. Finally, one important commitment that could be foreseeably implemented in the next six years is the expansion of a freight and public transit network in Mindanao that will link its northern and southern ports, and will therefore provide the necessary physical continuities for onward trade to the rest of the BIMP-EAGA region. There are in fact several growth corridors already conceived, in which national government intends to invest funds and geotechnical assistance strategically (Table 1).

Table 1. Innovation and Growth Corridors in Mindanao (NEDA, 2014).

\begin{tabular}{|l|l|}
\hline Project Name & Locations \\
\hline $\begin{array}{l}\text { Mindanao Food, Agribusiness and Logistics } \\
\text { Corridor }\end{array}$ & Tagum-Davao-General Santos \\
\hline Mindanao Industrial Trade Corridor & Western and Northern Mindanao \\
\hline Mindanao Food Basket Corridor & Central Mindanao-Bukidnon \\
\hline $\begin{array}{l}\text { Mindanao Biodiversity and Ecotourism } \\
\text { Corridor }\end{array}$ & $\begin{array}{l}\text { Surigao-Agusan-Davao Oriental including } \\
\text { former Paper Industries Corporation of the } \\
\text { Philippines (PICOP) concessionaire areas. }\end{array}$ \\
\hline Mindanao Mariculture and Trade Corridor & Zamboanga-Basilan-Sulu-Tawi-tawi \\
\hline
\end{tabular}

\subsection{Mindanao Strategic Development Framework}

Echoing many of the declarations in the national plans, but specifically produced by NEDA for the southern regions, is the Mindanao Strategic Development Framework 2010 to 2020. This document specifically begins: 
"Envisioned by 2020 is a peaceful and socially-inclusive Mindanao with a strong, sustainable, competitive, ICT-driven, agri-industrial, and resource-based economy that is responsive to local and global opportunities."

It recognizes Mindanao as the country's major agri-industrial base, and specifically mentions advantages in rubber, pineapple, banana and coffee, given that $1 / 3$ of its land area is devoted to agriculture. Mindanao is likewise recognized as a frontier for tourism, which can be developed, just as peace and social inclusiveness have been given prominence (NEDA, 2010). Five core strategies for development are mentioned by the same document: (a) sustainable resource-based industrialization; (b) growth with social equity; (c) efficient logistics support; (d) peace building; and (e) good governance and strong partnership. And specifically in relation to BIMP-EAGA and the furtherance of domestic as well as international trade, Mindanao is endowed with six Agri-Industrial Economic Zones registered with the Philippine Economic Zone Authority (PEZA). Two are located in Cagayan de Oro City, two in South Cotabato, one in General Santos City, and one in Davao City. Efforts are underway to develop three others in Bukidnon, Davao City and South Cotabato (NEDA, 2010).

Because of its focus, the MSDF is a more reliable guide to potentials and growth directions that Mindanao has been following at present. It notes that Mindanao's gross regional domestic product (GRDP) from 2002 to 2009 grew by $4.3 \%$ on the average, higher than the national and Luzon averages of $4.2 \%$ and $4.0 \%$, respectively. One should not assume however, that Mindanawon LGUs on the ground fit neatly into the framework, or are able to follow its broad pronouncements. Often, mutually-beneficial collaboration between national government agencies and LGUs, coupled with material or financial assistance from the former need to be provided.

\subsection{Mindanao 2020: Peace \& Development Framework Plan}

Finally, in terms of broad-strokes development intentions for the next decade until 2030, is the Mindanao Peace and Development Framework "MPDF 2020" (Mindanao Development Authority, 2012), that is being implemented by the recently-created in 2010 Mindanao Development Authority, which, incidentally, has also been designated as the Chair of the BIMP-EAGA Advisory Board for the Philippines. This MPDF 2020 is a guide that targets correction of historical injustices and inequalities experienced by Christians, Muslims, and indigenous peoples collectively called Lumads. It discusses enabling conditions such as the provision, maintenance, and expansion of infrastructure, as well as special purpose funds to accelerate development. Specific goals for 2016 (some of which have not yet been met) include peace agreements with Muslim separatists and Communist rebels, restoration of $30 \%$ forest cover, $80 \%$ completion of Comprehensive Land Use Plans and Comprehensive Development Plans for LGUs, etc. (from the MPDF 2020, Mindanao Development Authority, 2012). Similarly, by 2020, it is hoped that income poverty is down to $25 \%$, forest cover up to $40 \%$, and national roads paved with $90 \%$ coverage, among other goals. The framework plan contains many vision statements, and specific to potentials for BIMP-EAGA are the recognized need to provide maritime security. For instance, it states (Mindanao Development Authority, 2012):

"The first issue is the security of the international sea lane often referred to as the Lombok-Makassar and the Sulu Sea Lane... The Malacca Strait is currently much more visible and considered one of the busiest sea lanes between East and West. But in terms of greater deadweight capacity and suitability for bigger ships, the Lombok-Makassar-Sulu Sea Lane will assume greater primacy and strategic importance..." 
Throughout most of the document, however, peace-building, rule of law, and inclusivity seem to be the overall theme, which rightly recognize that Mindanao's long history of conflict is probably the biggest stumbling block to its rapid growth and closer integration with the two other major divisions of the Philippines: Visayas and Luzon. Notably however, the document - that is, the MPDF 2020, already recognizes that development must anticipate BIMP-EAGA's logistical and Information-CommunicationTechnology (ICT) needs - and goes so far as to mention serving even Timor Leste (Mindanao Development Authority 2012). Also important to the overall effort is the resolution of complex governance challenges, including the resolution of questions about the exact nature of the relationship between the religious and ethnic groups that occupy different areas of land. On the whole then, the MPDF 2020 document is remarkable for being an early example of thorough thinking about the problems, needs, and practical solutions for Mindanao.

\subsection{Priority Projects and Other Collateral Activities}

While there are several ongoing projects on the ground relating to development in Mindanao, it is not necessary to list and discuss all of them. Rather, a representative sample will be discussed. The National Priority Plan (NEDA, 2017) mentions at least two ongoing projects, both headed by the Department of Social Welfare and Development [DSWD], with direct impact on Mindanao: (1) Aftercare and Rehabilitation of Drug Dependents, and (2) Reducing Vulnerabilities from Hunger and Malnutrition in ARMM. Another office related to NEDA, the Public-Private Partnership Center also has several projects (some in partnership with other agencies, and LGUs) in Mindanao (Table 2). Clearly, from the following list, the priority is being placed on Region XI, where President Duterte hails from, with only one other airport project for Cagayan de Oro, a booming city that remains an intermodal hub for freight and passenger transfers between Mindanao and the rest of the Philippines to the north. These linkages also focus on strengthening transportation linkages.

Table 2. Priority infrastructure projects in Mindanao.

\begin{tabular}{|l|l|l|l|l|}
\hline Project Name & $\begin{array}{l}\text { Implementing } \\
\text { Agency }\end{array}$ & $\begin{array}{l}\text { Specific } \\
\text { Sector }\end{array}$ & $\begin{array}{l}\text { Budget } \\
\text { (Philippine Peso) }\end{array}$ & Start Date \\
\hline $\begin{array}{l}\text { Davao Airport- } \\
\text { Operations, Maintenance } \\
\text { and Dev't. Project } \\
\text { (OMD) }\end{array}$ & $\begin{array}{l}\text { Department of } \\
\text { Transportation } \\
\text { (DOTr) }\end{array}$ & Airports & P 40,570,000,000 & $\begin{array}{l}\text { 01 January } \\
\text { 2012 }\end{array}$ \\
\hline $\begin{array}{l}\text { Laguindingan Airport } \\
\text { OMD }\end{array}$ & DOTr & Airports & P 14,615,400,000 & $\begin{array}{l}\text { 01 January } \\
\text { 2012 }\end{array}$ \\
\hline $\begin{array}{l}\text { Mindanao Railway: } \\
\text { Tagum-Davao City-Digos }\end{array}$ & DOTr & Airports & P 31,544,407,000 & $\begin{array}{l}\text { 28 October } \\
\text { 2015 }\end{array}$ \\
\hline Davao-Sasa & $\begin{array}{l}\text { DOTr and } \\
\text { Phil.Ports } \\
\text { Authority }\end{array}$ & Seaports & $\begin{array}{l}\text { (none indicated } \\
\text { yet) }\end{array}$ & $\begin{array}{l}\text { (not yet } \\
\text { applicable) }\end{array}$ \\
\hline
\end{tabular}

\subsection{National Expenditure}

Likewise, the pattern of Mindanao-related expenditure in the recently released national budget appropriation of $\mathrm{P} 3.35 \times 10^{12}$ (Department of Budget and Management, 2017a) also shows appreciable focus in the southern Philippines (Table 3). A primer released by the DBM shows indicative figures (later fine-tuned in the actual budget, which contains 
modifications) that show what Mindanao can expect: overall, up to a 37.5\% higher budget of $\mathrm{P} 545.5 \times 10^{9}$ (Department of Budget and Management, 2017b). There is a notable prioritization on infrastructure spending under the "Build-Build-Build" Program of the Duterte Administration (Deuterte Nomics, 2017), and this has already been stepped up in 2017-2018 in various forms, as cited in the section above on representative projects. On the whole therefore, spending for development, especially in Mindanao, is also supportive of political promises to redistribute government investments across the Philippines, especially in areas that were historically unprioritized.

Table 3. Indicative government budget for Mindanao area.

\begin{tabular}{|c|c|c|c|}
\hline \begin{tabular}{|l} 
Region in \\
Mindanao
\end{tabular} & 2016 Budget & 2017 Budget & $\%$ Increase \\
\hline Region IX & P $69.9 \times 10^{9}$ & P $90.3 \times 10^{9}$ & $+29.2 \%$ \\
\hline Region X & P $84 \times 10^{9}$ & P $116.9 \times 10^{9}$ & $+39.2 \%$ \\
\hline Region XI & P $69.9 \times 10^{9}$ & P $108.3 \times 10^{9}$ & $+54.9 \%$ \\
\hline Region XII & P $65.8 \times 10^{9}$ & P $97.2 \times 10^{9}$ & $+47.7 \%$ \\
\hline \begin{tabular}{|l|} 
Autonomous Region of \\
Muslim Mindanao \\
\end{tabular} & P $53.7 \times 10^{9}$ & P $56.0 \times 10^{9}$ & $+4.3 \%$ \\
\hline
\end{tabular}

Source: DBM (Sept.2016) People's Proposed Budget.

\subsection{Analysis and Discussion}

Given the foregoing data and derived patterns, it can be said that the promises of the current administration were not all empty political rhetoric, but were translated into real projects now being implemented in Mindanao. What does need to discussed critically, however, is whether the apparent shift represents significant impact that will have beneficial multiplier effects in relation to the rest of ASEAN. For this concern, the focus on infrastructure is important: upgrading of airports and seaports for a still largely-maritime trade, as well as the expansion of the current highway network are the clearest indicators that Mindanao as a whole is being prepared for the influx of trade, consisting of commodities, people, and their ideas. This late-coming massive investment in Mindanao is part of that dramatic structural change evident in Indonesia, Malaysia, Singapore, and Thailand, and is related to globalization's new international division of labor, which engenders innovation as well as cultural resistance (McGee, 2002), and may likely prompt a regrouping of trade-area borders, subject to geotechnical inputs and spatial planning.

The plans, projects, and programs also recognize that historically advanced urban centers will continue to lead: Davao City, because it is the incumbent Chief Executive's home, Zamboanga City, because it is the most proximate jump-off to many parts of Malaysia, Brunei and Indonesia, and most apparently Cagayan de Oro City, which is the centrally-located doorway between Mindanao and the rest of the Philippines - in addition to the advantages of previously emplaced infrastructure, an educated young population, and relatively high peace-and-order status. Hence, it is logical that stepped up shipping commerce to Indonesia departs from either the Davao Gulf (or General Santos City's Sarangani Bay), while shipping to Malaysia departs from Zamboanga. Indeed, since the growth triangles as cooperative ventures gave rise to BIMP-EAGA in 1994, traditional sea 
routes have been used, between Zamboanga (the Philippines), Labuan (Malaysia), Manado, Ujung Pandang and Bitung (Malaysia), among others (Landingin \& Wadley, 2005). There are also smaller ports like Sandakan (Malaysia) and Cotabato City (the Philippines), which are expected to enjoy upgrades and receive more traffic in the near future.

\section{CONCLUSION AND RECOMMENDATIONS}

There is still much untapped potential in spatial and socioeconomic terms for the southern Philippines, considering that the sub-region of BIMP-EAGA is practically comprised not only of Brunei, parts of Indonesia (Kalimantan, Sulawesi, Maluku and Irian Jaya), Malaysia (Sabah, Sarawak and Labuan) and the Philippines (Mindanao and Palawan), but also all the various islands in between, including a yet unformalized extension to Timor Leste (Dent \& Richter, 2011). If only the results of a long peacebuilding process turn out to be beneficial for all, then one of the most substantial stumbling blocks to development and interconnectivity in Mindanao shall have been eliminated.

No matter what the outcome is in the near future, it is recommended to the various stakeholders that planning, geotechnical studies, and infrastructure preparation continue, as it is in the best interests of the Philippine state as well as its neighbors to attain shared stability in Mindanao, and growth in view of foreseeable trade integration later. For the Philippines, this would mean exploiting further the potentials of BIMP-EAGA, including stepped up talks with counterparts in Indonesia and Malaysia, as well as exploration of the various geographical sites, both in southern Mindanao and abroad, in order to determine what really needs to be built, and which policies and governance processes need to be established to ensure smooth cross-border liaisons that will lead to shared prosperity.

\section{REFERENCES}

Allen, A. (2003) Environmental Planning and Management of the Peri-Urban Interface: Perspectives on an Emerging Field. Environment and Urbanization, 15(1), 135-148.

Balisacan, A., Hill, H. \& Piza, S. F. (2008) Regional Development Dynamics and Decentralization in the Philippines: Ten Lessons from a "Fast Starter". ASEAN Economic Bulletin, 25(3), 293-315.

Barter, S. J. \& Côté, I. (2015) Strife of the Soil? Unsettling Transmigrant Conflicts in Indonesia. Journal of Southeast Asian Studies, 46(1), 60-85.

Boons, F. (2008) Self-Organization and Sustainability: The Emergence of a Regional Industrial Ecology. Emergence: Complexity \& Organization, 10(2), 41-48.

Dent, C. M. \& Richter, P., (2011) Sub-Regional Cooperation and Developmental Regionalism: The Case of BIMP-EAGA. Contemporary Southeast Asia, 33(1), 29-55.

Department of Budget and Management (2017a) People's Budget 2017. DBM, Manila,

Department of Budget and Management (2017b), Technical Notes on the 2017 Proposed National Budget. DBM, Manila, Available from: https://www.dbm.gov.ph/index.php/budgetdocuments/2017/technical-notes-on-the-2017-proposed-national-budget [Accessed March 2019]

Goh, D.P.S. \& Bunnell, T. (2013) Recentering Southeast Asian Cities. International Journal of Urban \& Regional Research, 37(3), 825-833.

Gomis, J. \& Turon, C. (2017) Drawing the "Boundaries", the Start of an Urban Planning Project. Geographia Technica, 12(2), 73-81.

Kanbur, R. \& Zhuang, J. (2013) Urbanization and inequality in Asia, Asian development review. 30(1), 131-147.

Landingin, N. \& Wadley, D. (2005) Export Processing Zones and Growth Triangle Development: The Case of BIMP-EAGA, Southeast Asia. Journal of International Development, 17(1), 67-96. 
Laquian, A.A. (2007), The Planning and Governance of Asia's Mega-Urban Regions. UN Expert Group Meeting on Population Distribution, Ubranization, Internal Migration, and Development. Woodrow Wilson Center Press, New York.

Liu, X., Liang, D. \& Derudder, B. (2017) Spatial Inequality in the Southeast Asian Intercity Transport Network. Geographical Review, 107(2), 317-335.

Mindanao Development Authority (2012) Mindanao Peace \& Development Framework 2020 [MPDF 2020]. Available from http://minda.gov.ph/planning/mindanao-2020-peace-and-developmentframework [Accessed March 2019]

McGee, T. (2002) Jalan, Jalan; Invading, Destroying, and Reconstructing the Southeast Asian City. Bijdragen tot de Taal-, Landen Volkenkunde: On the Road: Social Impact of Roads in Southeast Asia. 158(4), 637-652.

NEDA (2017) National Priority Plan. Available from: http://www.neda.gov.ph/2017-nationalpriority-plan [Accessed March 2019]

Duterte Nomics (2017) Build-Build-Build. Available from http://www.build.gov.ph/, [Accessed March 2019]

NEDA (2014) Philippine Development Plan [PDP]-Midterm Update (2011-2016). National Economic and Development Authority.

NEDA (2010) Mindanao Strategic Development Framework. Regional Development Office National Economic and Development Authority, Ortigas Center, Pasig City.

Suffian, F., Karim, M.R.S.A, Rosline, A.K., \& Fadzil K.S. (2013), Policy Fiasco: The Sabotage of Cabotage Policy Malaysia. International Journal of Social Science and Humanity, 3(6), 514517

Suzuki, N. (2013) Upholding Filipino Nationhood: The Debate Over Mindanao in the Philippine Legislature 1907-1913. Journal of Southeast Asian Studies. 44(2),266-291.

Tonev, P., Dvorak, Z., Sasinka, P., Kunc, J., Chaloupkova, M., \& Silhan, Z. (2017). Different Approaches to Defining Metropolitan Areas. Geographia Technica, 12(1), 108-120.

Waldron, D.G. (1997) Growth Triangles: a Strategic Assessment. Multinational Business Review, 5(1), 53-67.

Yang, E.C.L., Sharif, S.P, \& Khoo-Lattimore, C. (2015) Tourists' Risk Perception of Risky Destinations: The Case of Sabah's Eastern Coast. Tourism and Hospitality Research, 15(3), 206-221.

World Bank (2016c) Bangsamoro Conflict Monitoring System. Available from http://projects.worldbank.org/P152525/?lang=en\&tab=financial [Accessed March 2019]

Interviews and Informal Discussions (various times: January 2016 through December 2017).

A.H. Kimpo - Consultant, Mindanao Think-Tank and Office of the President;

A.D. Tolentino-Deputy Sec.General, Housing \& Urban Dev't. Coordinating Council;

L.U. Canals - NEDA Public-Private Partnership Center; and

A.A. Calizo - Supreme Court Staff 